\title{
A CRÍTICA DA CIÊNCIA PSICOLÓGICA EM WITTGENSTEIN
}

\author{
$\underline{\text { Naama Enéas da Silva Almeida }}{ }^{1}$ e Wagner Teles de Oliveira ${ }^{2}$ \\ 1. Bolsista FAPESB/CNPq, Graduanda em Psicologia, Universidade Estadual de Feira de Santana, e-mail: \\ naama_eneas@hotmail.com \\ 2. Orientador, Departamento de Ciência Humanas e Filosofia, Universidade Estadual de Feira de Santana, e-mail: \\ woteles@gmail.com
}

PALAVRAS-CHAVE: Wittgenstein; consciência; psicologia.

\section{INTRODUÇÃO}

Trata-se de analisar a crítica de Wittgenstein à gênese dos conceitos psíquicos, problematizando o estatuto de ciência do próprio saber psicológico. Wittgenstein resgata a gênese das confusões conceituais acerca das expressões psicológicas partindo da concepção de significado. Apresenta-se a tese de que tanto a perspectiva introspeccionista quanto a behaviorista fundamentam-se numa ficção gramatical que teria como principal consequência a indeterminação do significado dessas expressões. Como objetivo geral, pretendemos evidenciar como, a partir da noção de significado, Wittgenstein critica perspectivas de psicologia antagônicas e a própria gênese da ciência psicológica. Os objetivos específicos consistem em compreender as consequências conceituais da adoção do paralelismo psico-físico em psicologia; esclarecer as implicações da apropriação de um modelo de significado referencialista, fazendo ver que se trata da redução do discurso a um tipo de enunciado declarativo; explorar a crítica de Wittgenstein ao behaviorismo e ao introspeccionismo, a fim de fazer ver o quanto partilham o mesmo modelo de significado, a despeito de tratar-se de perspectivas antagônicas; avaliar em que medida a redução do discurso psicológico ao tipo "enunciados de observação" não seria uma consequência da subordinação da psicologia ao modelo de investigação das ciências naturais; esclarecer a relação entre o caráter inobservável da consciência alheia e a possibilidade de fazer ciência psicológica. Vale ressaltar a importância desse tema tanto no âmbito da psicologia quanto no da filosofia, uma vez que os enigmas relacionados ao mundo da consciência permeiam as discussões a respeito do estatuto e da possibilidade da ciência psicológica, sendo por outro lado caro à filosofia o conjunto de reflexões sobre a significação lógica e, por conseguinte, o discernimento entre os domínios do expressivo e do descritivo.

\section{MATERIAL E MÉTODOS OU METODOLOGIA (ou equivalente)}

O método de pesquisa em filosofia consiste na leitura e escrita de textos segundo técnicas de exegese e de escrita que caracterizam a atuação profissional na área. Assim, execução das atividades concernidas pela pesquisa privilegiou o cotejo com as fontes primárias da pesquisa, sobretudo Últimos Escritos sobre Filosofia da Psicologia, sem se furtar à apreciação de fontes secundárias, textos de destacados comentadores, que se inscrevem na tradição de leitura da obra de Wittgenstein, como são o caso de Arley Ramos Moreno, Antonio Marques, Joachim Schulte, P. M. S. Hacker, Meredith Williams e João Carlos Salles. Desse modo, o trabalho de pesquisa consistiu em duas etapas: a primeira envolvendo a leitura de textos indispensáveis à pesquisa, que foram 
cuidadosamente fichados, e a segunda realizada através da escrita. Essas duas etapas vinculam-se intrinsecamente pela elaboração de texto monográfico a ser gradativamente apresentado nas reuniões de nosso Grupo de Estudo e Pesquisa, de modo a permitir a apreciação dos resultados parciais da pesquisa por meio do debate das questões que ela envolve. A apresentação pública dos resultados da pesquisa, vale dizer, constitui um importante componente metodológico, pois permitiu à bolsista, além de familiarizar-se com expedientes que são característicos da pesquisa, debater sistematicamente os resultados de sua pesquisa, perfazendo assim as condições de elevação da qualidade do trabalho.

\section{RESULTADOS E/OU DISCUSSÃO (ou Análise e discussão dos resultados)}

Como resultado da pesquisa, compreendemos que a aparente distinção entre mundo da consciência e mundo físico resulta da aplicação de um modelo de significado próprio das ciências naturais que reclama uma referência às afirmações, ou seja, algo em que estas estejam fundamentadas. A aplicação deste modelo, denominado descritivo, resulta na assimilação indevida de conceitos psicológicos e expressões referentes à interioridade e exterioridade, como, por exemplo, a identificação do interior como oculto e do exterior como manifesto.

Sendo assim, engessou-se a ideia equivocada de que as expressões relativas ao mundo interior estariam baseadas na introspecção e as expressões relativas ao mundo físico na percepção exterior. As primeiras, portanto, estariam envoltas de um mistério próprio à condição das experiências interiores e as segundas seriam transparentes, possuindo objetividade. A ideia de dor, por exemplo, como uma entidade privada seria decorrente da ficção gramatical que relaciona a designação de uma sensação a algo interno e, consequentemente, insondável.

Ao analisar a gênese dos conceitos psicológicos, Wittgenstein propõe que apenas quando se referem a estados psíquicos de outrem, as expressões psicológicas podem ser interpretadas da perspectiva da observação. Além disso, o autor recusa a noção de que a relação entre palavra e ação seja mediada mentalmente; segundo ele, quando vinculadas às sensações, as palavras psíquicas baseiam-se nelas mesmas e não na sua observação em outrem. Logo, elas têm como fundamento sua própria afirmação, a qual, quando feita na primeira pessoa, não traduz conteúdos informativos, mas sim expressivos. Essas questões, no que tem de essencial, foram exploradas em texto monográfico, que segue em anexo, do qual deve resultar, quando menos, a elaboração de um artigo a ser publicado ou servir de base à elaboração da monografia de conclusão de curso.

\section{CONSIDERAÇÕES FINAIS (ou Conclusão)}

Tanto a psicologia da consciência quanto a psicologia behaviorista estão intimamente comprometidas com o lugar que escolhem para situar os seus elementos significativos, sendo a primeira determinada por elementos psíquicos e a segunda pelos fisiológicos. Para Wittgenstein, a determinação do significado em ambas localiza-se na própria gramática da linguagem, uma vez que o autor compreende que os determinantes do significado fundamentam-se nessa gramática. Contudo, isso não significa a redução do anímico à linguagem, uma vez que recairia numa nova confusão conceitual que necessariamente vincularia o externo ao manifesto. Nesse sentido, o caráter oculto dos 
elementos do mundo da consciência relaciona-se ao modo como utilizamos as expressões a este mundo vinculadas; ou seja, esse caráter oculto não advém da condição de ser interioridade, mas sim pelo fato de não serem expressos por uma gramática adequada.

Portanto, as condições que possibilitam o discurso psicológico são construídas ao longo do tempo, sendo o significado de uma palavra determinado pelo uso que dela se faz e não a partir de um referencial pré-determinado. A crítica à determinação exterior à gramática afirma que o estatuto de ciência do fazer psicológico depende da concepção de significado, do sentido que é atribuído às expressões psicológicas. Entende-se, por fim, o significado do comportamento linguístico a partir do contexto em que está situado, não estando mais vinculado nem a causas interiores e insondáveis nem ao reducionismo a elementos fisiológicos.

\section{REFERÊNCIAS}

HACKER, P.M.S. Wittgenstein: Meaning and Mind. Oxford: Blackwell, 1990. (Volume 3 of na Analytical Commentary on the Philosophical Investigations).

KÖHLER, W. Psicologia da Gestalt. Belo Horizonte: Itatiaia, 1980.

MARQUES, António. O interior: Linguagem e Mente em Wittgenstein. São Paulo: Edições Loyola, 2012.

MORENO, Arley R. Wittgenstein: através das imagens. $2^{\mathrm{a}}$ ed. Campinas: Editora da UNICAMP, 1995.

SALLES, João Carlos. O Cético e o Enxadrista: Significação e Experiência em Wittgenstein. Salvador: Quarteto Editora, 2013.

SCHULTE, Joachim. Experience and Expression: Wittgenstein's Philosophy of Psychology. Oxford: Clarendon Press, 2003.

TUGEDNHAT, Ernest. Lições Introdutórias à Filosofia Analítica da Linguagem. Ijuí: Editora Unijuí, 2006.

WATSON, John B. Behaviorism. Chicago: University of Chicago Press, 1959.

WILLIAMS, Meredith. Wittgenstein, Mind and Meaning. Routledge: Londo, 1999. WITTGENSTEIN, Ludwig. Últimos Escritos Sobre A Filosofia da Psicologia. Lisboa: Fundação Calouste Gulbenkian, 2007. 